\title{
Panel Analysis of Monetary Model of ASEAN-5 Exchange Rates
}

\author{
Noor Zainab.Tunggal ${ }^{1}$, Shariff Umar Shariff Abd. Kadir ${ }^{1} \&$ Venus-Khim Sen Liew ${ }^{2}$ \\ ${ }^{1}$ Labuan Faculty of International Finance, Universiti Malaysia Sabah, Jln Sg. Pagar, 87000 Federal Territory \\ Labuan, Malaysia \\ ${ }^{2}$ Faculty of Economics and Business, Universiti Malaysia Sarawak, 94300 Kota Samarahan Sarawak, Malaysia \\ Correspondence: Noor Zainab. Tunggal, Labuan Faculty of International Finance, Universiti Malaysia Sabah, Jln \\ Sg. Pagar, 87000 Federal Territory Labuan, Malaysia.
}

Received: August 13, 2018

Accepted: September 15, $2018 \quad$ Online Published: September 27, 2018

doi:10.5539/ibr.v11n11p1

URL: https://doi.org/10.5539/ibr.v11n11p1

\begin{abstract}
In this study, we examined whether the exchange rates in ASEAN-5 countries are driven by monetary fundamentals. We applied the panel unit root tests and found that the United States denominated nominal exchange rates of Malaysian Ringgit, Indonesian Rupiah, Philippines Peso, Singapore Dollar, and Thailand Baht are all integrated of order one. Meanwhile, relative money supply and relative real income are also integrated in the same order. Nonetheless, the relative interest rate is integrated in order zero, and it implies the uncovered interest rate parity held in ASEAN-5. By using a panel cointegration test pioneered by Pedroni (2000, 2004), we found evidence that there is a long-run relationship between nominal exchange rate and its monetary fundamentals. Consistent with the monetary model of the exchange rate, relative money supply is positively related to nominal exchange rates, while relative real income is negatively related to nominal exchange rates. Therefore, this study reveals the importance of relative real money supply and relative income for the exchange rate market players to predict and monitor ASEAN-5 exchange rates.
\end{abstract}

Keywords: monetary exchange rate model, panel cointegration, ASEAN

JEL Classification: C33, F31, F41

\section{Introduction and Overview}

Exchange rate determination has been a focus of research interest for decades, after the collapse of the Bretton Woods system of fixed exchange rate in the early 1970s. As we know, exchange rate plays an important role in economics development. With the right tools to predict the exchange rate behavior, it would help in enhancing the economic development of a country. For this reason, various exchange rate models including the monetary model of exchange rate have been postulated and empirically tested. However, many researchers in the 1980s such as Meese and Rogoff (1983), Frankel (1984) and Boughton (1988) have failed to find the satisfactory exchange rate model.

In the 1990s, Kearney and MacDonald (1990), Edison and Pauls (1993) and Rose (1996) have provided further evidence of the empirical failure of the monetary models in explaining exchange rate movements by using Engle and Granger's (1987) two-step procedure. Even though some researchers found evidence showing cointegrating relationship between monetary fundamentals and exchange rates, others could not obtain supportive evidence to validate the monetary models. In addition, Rapach and Wohar (2002) also pointed out that monetary fundamentals are appropriate to predict exchange rates at longer horizons only. Notably, Rapach and Wohar (2002) were able to provide evidence to support monetary model for half of the industrialized-countries under investigation using data that spanned over a century. There is also another strand of research that utilizes nonlinear techniques to improve the power of tests over the conventional test procedures (see for instance Liew, 2004; Liew et al., 2004; Liew, 2008)

On the other hand, Dabrowski et al. (2014) mentioned that panel procedures could be useful to overcome the low power of standard tests for a short span of data. Hsiao (2003) pointed out that panel data sets for economic research possess several major advantages of time-series data sets. Among others, it gives rise to a larger data set, thereby increasing the degree of freedom and improving the efficiency of econometric estimates. Moreover, panel data provides the foundation for aggregate analysis since time series analysis tends to yield less accurate if not misleading aggregate outcome (Hsiao, 2007). In this conjunction, a number of the most recent studies in 
exchange rate determinations that employed the panel technique found evidence that monetary model can predict exchange rate well (see Cerra and Saxena, 2010; Uz and Ketenci, 2010; Dabrowski et al., 2014). In particular, Dabrowski et al. (2014) found that money supply, real income and price level could explain the exchange rate behavior for the Central and Eastern European Countries case using the panel data analysis.

Overall, it can be understood that in the literature of monetary models, when estimated with the appropriate methods and a larger data set, they can be useful tools in determining the long-run relationship between exchange rate and its fundamentals. Previous studies using panel data analysis have examined the validity monetary model for European countries, industrialized countries and OECD countries cases (see Mark and Sul, 2001; Rapach and Wohar, 2004 and Dabrowski et al., 2014). In the same spirit of research, this study has aimed to contribute to the literature by employing panel procedures to test for the validity of the monetary model for ASEAN-5 countries in aggregate ${ }^{1}$.

In this article, we show how the United States dollar denominated the nominal exchange rates of ASEAN-5 countries are cointegrated with relative money supply and relative real income using the panel root tests and cointegration tests. Further analysis using fully modified ordinary least squares (FMOLS) as well as dynamics ordinary least squares (DOLS) estimation reveals that the estimated coefficients have the correct sign as predicted by the monetary model of exchange rate. As such, in line with the previous studies that have examined European countries, industrialized countries and OECD countries, this article provides empirical evidence supportive of the monetary model of exchange rate using the panel data approach for the case of ASEAN-5.

Section 2 describes the empirical model adopted in this study. Section 3 explains the data employed, while the methods of analysis are mentioned in Section 4. Section 5 presents the empirical results and interpretation. The concluding remarks are given in the last section.

\section{Empirical Model}

This study considers the following flexible-price monetary model attributed to Frankel (1976), Mussa (1976) and Bilson (1978):

$$
S_{i t}=\beta_{0}+\beta_{1} M_{i t}+\beta_{2} Y_{i t}+\beta_{3} I_{i t}+B_{4} D_{i t}+\varepsilon_{i t}
$$

where $S_{i t}$ represents the nominal exchange rate, which is measured as the domestic currency value of one United States dollar. $M_{i t}$ is relative money supply (domestic money supply - United States money supply), $Y_{i t}$ denotes relative real income (domestic real income - United States real income), $I_{i t}$ is relative interest rate (domestic interest rate - United States interest rate). $D_{i t}$ is dummy variable that takes into account the effect of the Global Financial Crisis where it takes the value one from 2008:q1 to 2008:q4 and zero otherwise.

denotes error term. ' $s$ are regression coefficients.

It is expected that $\quad{ }_{1}>0$, since an increase in relative money supply will cause domestic currency to depreciate.

On the other hand, a rise in relative real income will induce an increasing demand for money and causes domestic currency to appreciate. Hence, ${ }_{2}<0$. Besides, an increase in relative interest rate will lead to capital inflow. Consequently, domestic currency will appreciate $\left({ }_{3}<0\right)$. However, home currency could depreciate if inflation rate increases, causing a fall in relative interest rate $\left({ }_{3}>0\right)$. Note that if the uncovered

\footnotetext{
${ }^{1}$ The five largest economies in South-East Asia, namely Malaysia, Indonesia, Thailand, Singapore and the Philippines are the original founders of the Association of South-East-Asian Nations (ASEAN) and its most influential members in the $21^{\text {st }}$ century (Zhu et al., 2016).
} 
interest parity holds, relative interest rate equalizes to zero (Frankel, 1976). As such, the relative interest rate should be stationary at the level it will be excluded from Equation (1), and the resulting model is known as the forward-looking monetary model of exchange rate.

\section{Data for Estimation}

The balanced panel of quarterly data covers the period from 2000 quarter one to 2014 quarter four for ASEAN-5 countries namely Malaysia, Indonesia, the Philippines, Singapore and Thailand. Data of the United States dollar denominated the nominal exchange rates of the Malaysian Ringgit, the Indonesian Rupiah, the Philippines Peso, the Singapore Dollar, and the Thailand Baht, as well as relative money supply, relative interest rate, and relative real income which are included in this study. Treasury bill rate is a proxy to interest rates for the United States, Malaysia, Singapore and the Philippines (Baharumshah et al., 2002; Baharumshah and Masih, 2005; Islam and Hassan, 2006), and Lending rate is a proxy for interest rates for Thailand and Indonesia. Real gross domestic products (GDP) are used to represent the real incomes. Data of monetary aggregates, M2 are used for measuring the money supply for all countries. All variables are employed in the logarithmic form except for the interest rates.

\section{Methodology of the Study}

This study applies panel unit root tests such as the LLC test proposed by Levin et al. (2002) and IPS test proposed by Im et al. (2003) test to check for the stationarity of the variables. The test of unit root is crucial to determine whether the variables are integrated of order zero, one or more than one. The advantage of using panel unit roots test is it increases the number of cross section observation and hence improves the power of unit root test over the standard augmented Dickey-Fuller (ADF) tests (Levin and Lin, 1992). LLC assumes that the persistence parameters are common across cross-sections. In contrast, IPS allows the heterogeneity of persistence parameters across cross-sections. Besides, LLC assumes that all cross-sections are stationary in the alternative test. However, IPS test allows for some individual cross-sections to be stationary ${ }^{2}$. These two complementary tests are applied to check the stationarity of the series for the cointegration test in this study.

Based on the panel unit root tests results, we are able to identify the variables to be included in the cointegration test. The cointegration test pioneered by Pedroni $(2000,2004)$ is applied in this study to test the cointegrating between exchange rate and its fundamentals. The advantages of this method are it allows for multiple regressors and also for heterogeneity in the residuals across sectional units. Seven tests have been used which consist of four within-group tests and three between-group tests to check whether all variables are cointegrated. In order to perform Pedroni's cointegration test, it is necessary to obtain all the series integrated of order one.

Finally, the fully modified ordinary least squares (FMOLS) and dynamics ordinary least squares (DOLS) estimator suggested by Kao and Chiang (2000) are adopted to obtain the long-run coefficients. These estimators provide corrected standard pooled OLS in terms of serial correlation and regressors endogeneity that usually exist in a long-term relationship ${ }^{3}$. Thus, we can apply these models to check the coefficient and expected sign of each variable in the ASEAN-5 countries.

\section{Empirical Results}

\section{Panel unit root test results}

The results of panel unit root tests for ASEAN-5 countries are reported in Table 1. In this preliminary step of analysis, the integration order of nominal exchange rate, relative money supply, relative real income and relative interest rate are identified by using LLC and IPS tests. Basically, the exchange rate, relative money supply and relative real income are found to be nonstationary in levels. This is because the null hypothesis of nonstationary cannot be rejected at the 10 percent based on LLC and IPS tests, regardless of whether a trend or no trend has been included in the estimation. However, the relative interest rate is found to be stationary in level by both tests. Next, the relative money supply, relative income and nominal exchange rate series are subjected to another round of unit root tests in their first-differenced form. It is found that nominal exchange rate and relative money supply are stationary in their first-differenced form, according to the LLC test. In contrast, the relative income is not stationary in the first-differenced form by the LLC test.

${ }^{2}$ IPS formulated their model under the restrictive assumption that the data must be a balanced panel to compute the $t$-bar test statistic.

${ }^{3}$ See Kao and Chiang (2000) for further discussion on the estimation and the advantages of FMOLS and DOLS estimators. 
Table 1. Results of panel unit root tests

\begin{tabular}{|c|c|c|c|c|}
\hline \multirow[t]{2}{*}{ Series } & \multicolumn{2}{|l|}{ LLC } & \multicolumn{2}{|l|}{ IPS } \\
\hline & No Trend & Trend & No Trend & Trend \\
\hline \multicolumn{5}{|l|}{ Levels } \\
\hline \multirow[t]{2}{*}{$S$} & 0.729 & 1.669 & -1.146 & -2.571 \\
\hline & $(0.767)$ & $(0.952)$ & $(0.816)$ & $(0.127)$ \\
\hline \multirow[t]{2}{*}{$M$} & 1.797 & -1.254 & 0.097 & -2.444 \\
\hline & $(0.964)$ & $(0.105)$ & (1.000) & $(0.176)$ \\
\hline \multirow[t]{2}{*}{ Y } & 2.448 & 0.427 & 0.074 & -2.190 \\
\hline & $(0.993)$ & $(0.665)$ & $(1.000)$ & $(0.352)$ \\
\hline \multirow[t]{2}{*}{$I$} & -3.007 & -1.806 & $-2.937(0.000) * * *$ & $-3.199(0.002) * * *$ \\
\hline & $(0.001)^{* * *}$ & $(0.036)^{* *}$ & & \\
\hline \multicolumn{5}{|c|}{ First Differences } \\
\hline$S$ & -9.740 & -8.042 & -6.842 & -6.590 \\
\hline & $(0.000)^{* * *}$ & $(0.000) * * *$ & $(0.000)^{* * *}$ & $(0.000)^{* * *}$ \\
\hline$M$ & -7.931 & -8.669 & -4.611 & $-5.045(0.000) * * *$ \\
\hline & $(0.000)^{* * *}$ & $(0.000) * * *$ & $(0.000)^{* * *}$ & \\
\hline$Y$ & 11.343 & 16.614 & $-4.111(0.000) * * *$ & $-4.265(0.000)^{* * * *}$ \\
\hline & $(1.000)$ & $(1.000)$ & & \\
\hline$I$ & - & - & - & - \\
\hline
\end{tabular}

Notes. $* *$ and $* * *$ denote rejection of the null of non-stationary at 5 and 1 percent levels of significance, respectively. Probability values are given in parentheses.

According to the IPS test, all variables are found to be stationary in the first-differenced form. IPS has an advantage over LLC, in which it takes into account the heterogeneity across countries, (Quah, 1992, 1994; Ling et al., 2010). Therefore, we can conclude that with the IPS test, all variables are integrated of order one except for the relative interest rate, which is integrated of order zero. Hence, only three variables will be included in the test for cointegration relationship between nominal exchange rate and its fundamentals (relative money supply, relative real income).

\section{Panel cointegration test results}

Table 2 depicts the results of the panel cointegration test. According to Pedroni's cointegration test results, the null hypothesis of no cointegration can be rejected by all test statistics at conventional levels of significance. In other words, all statistics show the presence of a long - run relationship between the nominal exchange rates of ASEAN-5 countries and its monetary determinants which are relative money supply and relative real income. Therefore, consistent with Cerra and Saxena (2010), Uz and Ketenci (2010) and Dabrowski et al. (2014), the current study is able to provide evidence supportive of the monetary model of exchange rate using panel data analysis for the case of ASEAN-5.

Table 2. Results of panel cointegration tests

\begin{tabular}{ll}
\hline Test Statistic & No Trend \\
\hline Within-dimension (Panel) & \\
\hline Panel v-Statistic & $3.030(0.001)^{* * *}$ \\
Panel rho-Statistic & $-3.287(0.001)^{* * *}$ \\
Panel PP-Statistic & $-3.166(0.001)^{* * *}$ \\
Panel ADF-Statistic & $-1.408(0.080)^{*}$ \\
\hline Between-dimension (Group) & \\
\hline Group rho-Statistic & $-3.797(0.000)^{* * *}$ \\
Group PP-Statistic & $-4.082(0.000)^{* * *}$ \\
Group ADF-Statistic & $-2.213(0.014)^{* *}$ \\
\hline
\end{tabular}

Notes. $*, * *$ and $* * *$ denote significance level at 10,5 and 1 percent levels, respectively. Probability values are given in parentheses.

\section{Estimated long-run elasticities}

The final step is to estimate the cointegrating vector by using FMOLS and DOLS pioneered by Kao and Chiang (2000). As relative interest rate is integrated in order zero, it implies that the forward-looking monetary model should be estimated, instead of the flexible-price monetary model. The estimated coefficients of the forward-looking monetary model that correspond to long-run elasticities are reported in Table $3^{4}$. The

\footnotetext{
${ }^{4}$ We found that the coefficient for dummy variable is insignificant in which we can conclude that the global financial crisis does not seem to give any effect toward the monetary model of the exchange rate in ASEAN-5 countries.
} 
coefficients for relative money supply are positive, while the coefficients of relative income are negative. Indeed, these coefficients are statistically significant at the $1 \%$ level. These estimated signs of the coefficients are consistent with the prediction of the monetary model.

Moreover, the FMOLS and DOLS estimators show that the coefficients for relative money supply are 0.380 and 0.346 respectively for ASEAN-5 countries. Thus, based on the FMOLS and DOLS results, a one percent increase (decrease) in relative money supply can be associated to about 0.4 percent depreciation (appreciation) in the nominal exchange rate. Meanwhile, the coefficients for relative income are -0.952 and -0.957 by the FMOLS and DOLS estimators respectively. Here, it can be said that a one percent increase (decrease) in relative real income will tend to appreciate (depreciate) the exchange rate by nearly 1 percent.

Table 3. Results of long-run coefficients

\begin{tabular}{lll}
\hline Coefficients & FMOLS & DOLS \\
\hline$\beta_{1}$ & $0.380(0.000)^{* * *}$ & $0.346(0.000)^{* * *}$ \\
$\beta_{2}$ & $-0.953(0.000)^{* * *}$ & $-0.957(0.000)^{* * *}$ \\
$\beta_{4}$ & $-0.020(0.172)$ & $-0.025(0.176)$ \\
\hline
\end{tabular}

Notes. $\quad * * *$ denotes significance at 1 percent level. Probability values are given in parentheses.

\section{Concluding Remarks}

In this study, we have attempted to examine whether monetary fundamentals could explain the ASEAN-5 exchange rates behavior over the 2000 quarter one to 2014 quarter four periods. In other words, we would like to know whether monetary model does hold for ASEAN-5 countries. From our findings, we summarise that nominal exchange rate, relative money supply and relative real income are stationary in their first-differenced according to the IPS test. However, relative interest rate is stationary in the level.

Based on Pedroni's panel cointegration test, we found evidence that nominal exchange rate and relative money supply as well as relative income are cointegrated. The coefficients of relative money supply and relative income are significant and the estimated signs are in line with the monetary model's prediction. Therefore, monetary model is valid for the United States dollar denominated nominal exchange rates of ASEAN-5 countries, namely Malaysia, Indonesia, Singapore, Thailand and the Philippines. In addition, the analysis of dummy variable which has been undertaken here to capture the effect of the Global Financial Crisis has extended our knowledge that this event does not seem to affect the exchange rate model in ASEAN-5 countries.

The issues of exchange rate behavior for ASEAN-5 against the United States Dollar are important to policy makers, researchers, private enterprise and investors, especially after the global financial chaos that occurred in the end 2008. Based on the empirical results, we found out that ASEAN-5 countries have a strong significant impact on the United States but are not affected by the global financial crisis. Therefore, several policy implications can be suggested. First, private enterprise and investors should focus on one indicator such as real income, as a rise in real income will lead to ASEAN-5 countries appreciates due to the increase in money demands. Indirectly, this will also increase the capital account that surpasses the decline in the trade balance. Second, if the money supply differentials are referred by the policy makers, investors and private enterprise, an increase in money supply differentials will cause the five major ASEAN countries vis-à-vis USD to depreciate. Fourth, the behavior of long-run impact must be continuously identified. This is because the policy makers, the private enterprise and investors could evaluate, manage, improve and use it for the benefit of their long-run financial and economic targets. As for the policy implications of our findings, since uncovering interest parity holds for ASEAN-5 nominal exchange rates, there is no opportunity for arbitrating based on the differentials between ASEAN-5 and United States interest rates. It also implies that one could not predict these exchange rates by the relative interest rates. Nevertheless, this study reveals the importance of relative real money supply and relative income for the exchange rate market players to predict and monitor the ASEAN-5 exchange rates.

Several recommendations for future research are suggested to fill up the literature gap. First, the contegrating relationship between exchange rate and its fundamentals for ASEAN-5 countries against the United States has been identified. The long run relationship may exist for ASEAN-5 countries against other world's major currencies such as the euro, the British pound and the Japanese Yen. Second, the interest rate differentials could not be included in testing long-run relationship due to Pedroni's cointegration test, which is only suitable for nonstationary variables in level form. Thus, in the future research, panel autoregressive-distributed lag framework will be applied. Moreover, there might be a nonlinear relationship that exists between exchange rate and its fundamentals. Therefore, it would be interesting to know the exchange rate movements in terms of nonlinearity not only for ASEAN-5, but also for other regions. 


\section{References}

Baharumshah, A. Z., \& Masih, A. M. M. (2005). Current account, exchange rate dynamics and the predictability: the experience of Malaysia and Singapore. Journal of International Financial Markets, Institutions and Money, 15(3), 255-270. https://doi.org/10.1016/j.intfin.2004.06.002

Baharumshah, A. Z., Masih, A. M. M., \& Azali, M. (2002). The stock market and the ringgit exchange rate: a note. Journal of Japan and the World Economy, 14(4), 471-486. https://doi.org/10.1016/S0922-1425(02)00019-1

Bilson, J. (1978). The monetary approach to the exchange rate-some empirical evidence. IMF Staff Papers, 25(1), 48-75. https://doi.org/10.2307/3866655

Boughton, J. (1988). The monetary approach to exchange rate: What now remains? Princeton Studies in International Finance, No. 171, Princeton New Jersey: Princeton University Press.

Cerra, V., \& Saxena, S. C. (2010). The monetary model strikes back: evidence from the world. Journal of International Economics, 81(2), 184-196. https://doi.org/10.1016/j.jinteco.2010.03.003

Chen, J., \& Mark, N. C. (1996). Alternative Long-Horizon Exchange rate predictors. International Journal of Finance and Economics, 1(4), 229-250. https://doi.org/10.1002/(SICI)1099-1158(199610)1:4<229::AID-IJFE23>3.0.CO;2-6

Dabrowski, M. A., Papiez, M., \& Smiech, S. (2014). Exchange rates and monetary fundamentals in CEE countries: Evidence from a panel approach. Journal of Macroeconomics, 41(C), 148-159. https://doi.org/10.1016/j.jmacro.2014.05.005

Edison, H., \& Pauls, B. D. (1993). A re-assessment of the relationship between real exchange rates and real interest rates: 1974-1990. Journal of Monetary Economics 31, 165-187. https://doi.org/10.1016/0304-3932(93)90043-F

Engle, R., \& Granger, C. (1987). Cointegration and error correction: Representation, estimation and testing. Econometrica, 55(22), 251-276. https://doi.org/10.2307/1913236

Frankel, J. A. (1976). A monetary approach to exchange rate: Doctrinal aspects and empirical evidence. Scandinavian Journal of Economics, 78(2), 200-224. https://doi.org/10.2307/3439924

Frankel, J. A. (1984). Tests of monetary and portfolio balance models in exchange rate determination: sampling error misspecification. In: Frankel J.A (Ed.), Exchange rate and international macroeconomics, The University of Chicago Press, Chicago, 67-105.

Hsiao, C. (2003). Analysis of Panel Data, $2^{\text {nd }}$ edition.UK: Cambridge Universirty Press. https://doi.org/10.1017/CBO9780511754203

Hsiao, C. (2007). Panel data analysis—advantages and challenges, Test, 16(1), 1-22. https://doi.org/10.1007/s11749-007-0046-X

Im, K. S., Pesaran, M. H., \& Shin, Y. (2003. Testing for unit roots in heterogeneous panels. Journal of Econometrics, 115(1), 53-74. https://doi.org/10.1016/S0304-4076(03)00092-7

Islam, M. F., \& Hasan, M. S. (2006). The monetary model of the dollar-yen exchange rate determination: A cointegration approach. International Journals of Business and Economics, 5(2), 129-145.

Kao, C., \& Chiang, M. (2000). On the estimation and inference of a cointegrated regression in panel data, in Baltagi, B., ed. Nonstationary panels, panel cointegration, and dynamic panels. Advances in Econometrics, 15. Amsterdam, New York and Tokyo, Elsevier Science, 179-222. https://doi.org/10.1016/S0731-9053(00)15007-8

Kearney, C., \& MacDonald, R. (1990). Rational expectations, bubbles and monetary models of the exchange rate: the Australian/US Dollar rate during the recent float. Australian Economic Papers, 29(54), 1-20. https://doi.org/10.1111/j.1467-8454.1990.tb00467.x

Levin, A., Lin, C., \& J. Chu, J. (2002). Unit root tests in panel data: asymptotic and finite-sample properties. Journal of Econometrics, 108(1), 1-24. https://doi.org/10.1016/S0304-4076(01)00098-7

Liew, V. K. S. (2004). Nonlinear adjustment of ASEAN-5 real exchange rates: Symmetrical or asymmetrical? Economics Bulletin, 6(8), 1-8.

Liew, V. K. S. 2008. Monetary Models of Exchange Rate: Nonlinearity Matters. USA: Verlag Dr. MÜller Aktiengesellschaft \& Co. KG. 
Liew, V. K. S., Baharumshah, A. Z., \& Lau, E. (2004). Nonlinear adjustment towards purchasing power parity in ASEAN exchange rates. ICFAI Journal of Applied Economics, III(6), 7-18.

Ling, T. H., Liew, V. K. S., \& Syed Khalid Wafa, S. A. W. (2010). Does fisher hypothesis hold for the East Asian economies an application of panel unit root tests. Comparative Economic Studies, 52(2). 273-285. https://doi.org/10.1057/ces.2010.4

Mark, N. C. (1995). Exchange rate and fundamentals: evidence on long-horizon predictability. American Economic Review, 85(1), 201-218.

Mark, N. C., \& Sul, D. (2001). Nominal exchange rate and monetary fundamentals: Evidence from a small post-bretton woods panel, Journal of International Economics, 53(1), 29-52. https://doi.org/10.1016/S0022-1996(00)00052-0

Meese, R. A., \& Rogoff, K. (1983). Empirical exchange rate models of the seventies: Do they fit out of sample? Journal of International Economics, 14, 3-24. https://doi.org/10.1016/0022-1996(83)90017-X

Miyakoshi, T. (2000). The monetary approach to the exchange rate: empirical observations from Korea. Applied Economics Letters, 7(12), 791-794. https://doi.org/10.1080/135048500444813

Mussa, M. (1976). The exchange rate, the balance of payments, and monetary and fiscal policy under a regime of controlled floating. Scandinavian Journal of Economics, 78(2), 229-248. https://doi.org/10.2307/3439926

Pedroni, P. (2000). Fully modified OLS for heterogeneous cointegrated panels. Advance Econometrics, 15, 93-130. https://doi.org/10.1016/S0731-9053(00)15004-2

Pedroni, P. (2004). Panel cointegration; asymptotic and finite sample properties of pooled time series tests with an application to the PPP hypothesis. Econometric Theory, 20(3), 597-625. https://doi.org/10.1017/S0266466604203073

Quah, D. (1994). Exploiting cross section variation for unit root inference in dynamic data. Economics Letters, 44(1), 9-19. https://doi.org/10.1016/0165-1765(93)00302-5

Rapach, D. E., \& Wohar, M. E. (2002). Testing the monetary model of exchange rate determination: new evidence from a century of data. Journal of International Economics, 58(2), 359-385. https://doi.org/10.1016/S0022-1996(01)00170-2

Rapach, D. E., \& Wohar, M. E. (2004). Testing the monetary model of exchange rate determination: a closer look at panels, Journal of International Money and Finance, 23(6), 867-895. https://doi.org/10.1016/j.jimonfin.2004.05.002

Rose, A. K. (1996). Explaining exchange rate volatility: an empirical analysis of "the holy trinity" of monetary interdependence, fixed exchange rate and capital mobility, Journal of International Money and Finance, 15(6), 925-945. https://doi.org/10.1016/S0261-5606(96)00041-1

Shiller, R. J., \& Perron, P. (1985). Testing the random walk hypothesis: power versus frequency of observation. Economic Letters, 18(4), 381-386. https://doi.org/10.1016/0165-1765(85)90058-8

Uz, I., \& Ketenci, N. (2010). Exchange rate determination: monetary approach in the new EU members and Turkey, Applied Economics Letter, 17(10), 963-967. https://doi.org/10.1080/13504850802599458

Zhu, H., Duan, L., Guo, W., \& Yu, K. (2016). The effects of FDI, economic growth and energy consumption on carbon emissions in ASEAN-5: Evidence from panel quantile regression, Economic Modelling, 58, 237-248. https://doi.org/10.1016/j.econmod.2016.05.003

\section{Copyrights}

Copyright for this article is retained by the author(s), with first publication rights granted to the journal.

This is an open-access article distributed under the terms and conditions of the Creative Commons Attribution license (http://creativecommons.org/licenses/by/4.0/). 